\title{
PERANCANGAN APLIKASI PENGELOLAAN BUKU INDUK SISWA BERBASIS WEB MENGGUNAKAN MODEL WATERFALL PADA SDN RAWAMANGUN 09
}

\author{
Dwi Novia Satriana ${ }^{1}$, Verdi Yasin ${ }^{2 *}$, Anton Zulkarnain Sianipar ${ }^{3}$ \\ Prodi Sistem Informasi, STMIK Jayakarta \\ Jalan Salemba I Nomor 10 Jakarta Pusat 10430 Indonesia \\ *e-mail:satriananovia30@gmail.com,verdiyasin29@gmail.com, antonz.jayakarta@gmail.com \\ 17573006@stmik.jayakarta.ac.id, verdi_yasin@stmik.jayakarta.ac.id
}

Received: July 20, 2021, Revised: August 15, 2021 Accepted: August 20, 2021

\begin{abstract}
Abstrak
Bertambahnya peserta didik baru yang diterima di SDN Rawamangun 09, membuat dokumen buku induk siswa semakin menumpuk dan menyita banyak tempat di lemari arsip dan makin lama akan rusak. Hal itu membuat terhambatnya penyajian laporan data siswa jika sewaktu-waktu dibutuhkan karena harus mencari dengan membuka dokumen dalam buku besar di lemari arsip sehingga kurang efektif dan efisien. Penelitian ini membahas tentang perancangan sebuah aplikasi sistem informasi yang bertujuan untuk mempermudah dan mempercepat proses penyimpanan dan pencarian data siswa, dengan menggunakan metode blackbox saat pengujian sistemnya. Oleh karena itu penulis mencoba merancang aplikasi pengelolaan buku induk siswa yang dibuat dengan menggunakan metode waterfall, sehingga aplikasi ini dapat diakses secara online. Dengan adanya aplikasi pengelolaan buku induk siswa ini diharapkan dapat memudahkan dalam pencarian data siswa yang masih aktif ataupun data siswa alumni serta memudahkan dalam hal penyimpanan datanya.
\end{abstract}

Kata kunci: Buku induk, perancangan applikasi, web.

\begin{abstract}
The increasing number of new students accepted at SDN Rawamangun 09, makes the student master book documents pile up and take up a lot of space in the filing cabinet and will be damaged over time. This hampers the presentation of student data reports if needed at any time because they have to search by opening documents in a ledger in the filing cabinet so that it is less effective and efficient. This study discusses the design of an information system application that aims to simplify and speed up the process of storing and searching student data, using the blackbox method when testing the system. Therefore, the author tries to design a student book management application that is made using the waterfall method, so that this application can be accessed online. With this student book management application, it is hoped that it will make it easier to search for active student data or alumni student data and make it easier to store data.
\end{abstract}

Keywords: Master book, app design, web.

\section{Pendahuluan (Introduction)}

Bertambahnya murid baru yang mendaftar dan menjadi anak didik di SDN Rawamangun 09 membuat semakin bertambahnya data siswa yang harus ditulis tangan di buku induk siswa. Hal ini menyebabkan semakin menumpuknya berkas yang harus disalin ke dalam buku induk, dan tidak bisa dihindarkan dari kesalahan tulis ataupun coretan-coretan yang tidak perlu. Dan dalam hal 
penyimpanan kurang efektif dan efisien karena memerlukan ruang yang luas karena berkas yang menumpuk dan berserakan. Serta karena masih ditulis dalam kertas lama-kelamaan akan usang dan rusak, padahal buku induk seharusnya bisa dipakai dalam waktu yang cukup lama sebagai dokumen penting seorang siswa dan sebagai bukti bahwa siswa tersebut pernah menempuh pendidikan ataupun merupakan alumni sekolah tersebut. Karena masih disimpan dalam rak ataupun lemari sehingga dapat menghambat petugas TU dalam memberikan laporan atau pencarian data siswa jika diperlukan sewaktu-waktu.

Untuk menghadapi permasalahan tersebut dan untuk memenuhi standar laporan yang terstruktur, rapi, cepat dan dapat dipertanggungjawabkan maka diperlukan sebuah sistem yang dapat dipergunakan oleh petugas TU sehingga mempermudah dalam hal pengelolaan data siswa di buku induk. Sebuah aplikasi pengelolaan yang dapat digunakan untuk menginput data siswa, mengolah dan menyimpannya serta dapat membuat laporan terstuktur dan rapi tanpa harus menulis tangan. Dengan menggunakan model waterfall dalam pengembangan sistemnya karena model pengembangan ini walaupun kuno tetapi, paling sering digunakan dan untuk pengerjaan project akan terjadwal dengan baik dan mudah dikontrol sehingga akan memudahkan dalam melakukan manajemen dan merancang requirement. Diharapkan dengan adanya sistem aplikasi ini semua data siswa dari mulai masuk sampai keluar sekolah tersebut tidak lagi menggunakan kertas sebagai media penyimpananya.

\section{Tinjauan Literatur (Literature Review)}

Penulis mengambil beberapa rujukan dalam penelitian. Pertama adalah "Sistem Informasi Buku Induk Siswa" yang dilakukan oleh [1]. Penelitian ini membahas tentang perancangan dan implementasi sistem informasi buku induk siswa dengan menggunakan bahasa pemrograman PHP, database MySQL dan Framework Bulma serta menggunakan Black Box Testing sebagai perangkat lunak pengujiannya. Penelitian selanjutnya dilakukan oleh [2] yang bertajuk "Rancang Bangun Aplikasi Buku Induk Siswa Berbasis Web Pada MTs Negeri Kertajati" mengenai rancang bangun aplikasi buku induk siswa berbasis web dengan menggunakan metode pengembangan sistemnya SDLC atau Software Development Life Cycle atau sering disebut juga Systems Development Life Cycle. Penelitian ketiga bertajuk "Perancangan Sistem Informasi Buku Induk Siswa Berbasis Web Di Madrasah Diniyah Ma'hadil Islam” yang dilakukan oleh [3].

\section{Metode Penelitian (Research Method)}

\subsection{Metode Pengumpulan Data}

Teknik pengumpulan data dalam penelitian merupakan langkah yang paling utama, karena tujuan utama dari penelitian adalah mendapatkan data. Tanpa mengetahui teknik pengumpulan data, maka peneliti tidak akan mendapatkan data yang memenuhi standar data yang ditetapkan. Berikut adalah teknik pengumpulan data yang dipakai :

a. Observasi, yaitu teknik pengumpulan data yang dilakukan dengan cara pengamatan langsung di SDN Rawamangun 09 Jakarta Timur, hal itu dilakukan untuk mendapatkan data dan dokumen secara langsung yang benar-benar terjadi di dalam pelaksanaan atau penelitian. Hasil observasi berupa foto keadaan di SDN Rawamangun 09.

b. Wawancara, merupakan teknik pengumpulan data dilakukan dengan cara tanya jawab dengan petugas yang bersangkutan dan yang berwenang untuk memperoleh data informasi yang diperlukan dan mengetahui alur pengelolaan buku induk siswa pada sekolah tersebut. Peneliti mempersiapkan beberapa pertanyaan untuk dijadikan bahan data atau sumber yang relavan dalam penelitian ini.

c. Dokumentasi, merupakan catatan peristiwa yang sudah berlalu, dokumen bisa berbentuk tulisan, gambar atau karya-karya monumental dari seseorang. Dokumen yang berbentuk tulisan misalnya catatan sejarah, biografi ataupun peraturan kebijakan. 
d. Studi Pustaka, merupakan teknik pengumpulan data dilakukan dengan cara mempelajari dalam bentuk literature, buku, internet dan sumber tertulis lainnya yang berkaitan atau berhubungan dengan judul penelitian serta mencari referensi teori yang relevan dengan permasalahan yang telah sebelumnya ditemukan.

3.2 Analisis Kebutuhan Sistem

1. Kebutuhan Perangkat Keras (Hardware)

Analisis Kebutuhan Perangkat Keras (Hardware) Kebutuhan perangkat keras, pengembangan perangkat atau hardware adalah seluruh komponen peralatan yang membentuk suatu sistem komputer dan peralatan lainnya yang memungkinkan komputer dapat melaksanakan tugas dan fungsinya. Spesifikasi sarana pendukung perangkat keras adalah sebagai berikut:

1 Processor Core I3

2 RAM 8 GB

3 Hardisk $500 \mathrm{~GB}$

4 Monitor 14"

5 Keyboard USB

2. Analisis Kebutuhan Perangkat Lunak (Software)

Pemakaian komputer tidak terlepas dari penggunaan software sebagai sarana pendukung program yang sedang dibuat. Untuk merancang program aplikasi ini klasifikasi software yang digunakan adalah :

1. Microsoft Windows 764 bit

2. XAMPP 5.6.40

3. Laravel

4. Crudbooster

5. Text Editor Visual Studio Code

6. Google Chrome

3.3 Analisis Sistem Yang Berjalan

Dalam Analisis sistem yang berjalan menggunakan metode desain dilakukan dengan pendekatan terstruktur menggunakan diagram alir (flowchart), Use Case Diagram, dan Activity Diagram.

3.4 Analisis Sistem \& Aplikasi

Dalam penelitian ini akan menghasilkan suatu aplikasi berbasis web yang akan digunakan untuk mengelola dan menyimpan data buku induk siswa dari mulai masuk sekolah sampai dengan lulus. Kebutuhan sistem adalah sebagai berikut :

1. Sistem akan terkoneksi ke server database melalui koneksi internet dari pc atau laptop pengguna.

2. Sitem akan menyimpan semua data ke dalam database.

3. Sistem akan memberikan informasi yang dibutuhkan oleh pengguna.

Dari hasil wawancara yang sudah dilakukan oleh peneliti dengan admin atau petugas tata usaha, ditemukan beberapa sistem informasi yang sudah dipakai oleh petugas dalam pengelolaan data induk siswa dalam merekap data-data siswa dari yang aktif, sudah pindah dan juga yang sudah menjadi alumni. sampai sekarang yaitu dengan excel. Sistem untuk mengelola data siswa yang sekarang masih menggunakan sistem manual.

\section{Hasil dan Pembahasan (Results and Analysis)}

\subsection{Perancangan Struktur Tabel Database}

Desain basis data menjelaskan nama tabel, tipe file, media penyimpanan yang digunakan, primary key, panjang record, dll. Spesifikasi basis data yang digunakan dalam sistem yang akan dibangun Berikut ini adalah struktur -struktur tabel yang digunakan dalam pembuatan database untuk aplikasi buku induk siswa di SDN Rawamangun 09: 
Volume 2, Nomor 2, Oktober 2021 halaman 90-101

https://jurnal.amikwidyaloka.ac.id/index.php/awl

jurnal@amikwidyaloka.ac.id / editor.jurnalwidya@gmail.com

a. Perancangan Tabel Siswa

Nama tabel : siswa

Media : Hardisk

Primary Key : id_Siswa

Tabel 1.1 Tabel Siswa

\begin{tabular}{|c|c|c|c|c|c|}
\hline Field & Type & Length & PK & FK & Keterangan \\
\hline Id_siswa & int & 11 & $\checkmark$ & & Id siswa \\
\hline Nama & Varchar & 200 & & & Nama lengkap Siswa \\
\hline Nama_panggilan & Varchar & 200 & & & Nama Panggilan siswa \\
\hline nis & Int & 11 & & & Nomor induk siswa \\
\hline nisn & Int & 11 & & & $\begin{array}{lll}\text { Nomor induk } & \text { siswa } \\
\text { nasional } & & \\
\end{array}$ \\
\hline jenis_kelamin & Varchar & 50 & & & Jenis kelamin siswa \\
\hline tmpt_lahir & Varchar & 50 & & & Tempat lahir siswa \\
\hline tgl_lahir & Date & & & & Tanggal lahir siswa \\
\hline agama & Varchar & 50 & & & Agama siswa \\
\hline kewarganegaraan & Varchar & 100 & & & Kewarganegaraan siswa \\
\hline anak_ke & int & 10 & & & Siswa anak keberapa \\
\hline jml_saudara & int & 10 & & & $\begin{array}{l}\text { Jumlah saudara kandung } \\
\text { siswa }\end{array}$ \\
\hline status_anak & Varchar & 50 & & & Status siswa \\
\hline foto & Varchar & 200 & & & Foto siswa \\
\hline bahasa & Varchar & 200 & & & $\begin{array}{lll}\text { Bahasa } & \text { yang } & \text { dipakai } \\
\text { siswa } & & \\
\end{array}$ \\
\hline status_aktif & Varchar & 100 & & & Status siswa di sekolah \\
\hline alamat & Varchar & 200 & & & $\begin{array}{lll}\text { Alamat tempat tinggal } \\
\text { siswa }\end{array}$ \\
\hline Kecamatan_id & Int & 11 & & & $\begin{array}{ll}\text { Kecamatan } & \text { tempat } \\
\text { tinggal siswa } & \end{array}$ \\
\hline Kota_id & Int & 11 & & & $\begin{array}{lll}\text { Kota } & \text { tempat tinggal } \\
\text { Siswa } & & \end{array}$ \\
\hline Provinsi_id & Int & 11 & & & $\begin{array}{l}\text { Provinsi tempat tinggal } \\
\text { siswa }\end{array}$ \\
\hline
\end{tabular}

b. Perancangan Tabel Kelarga Siswa

Nama tabel : klrg_siswa 
Volume 2, Nomor 2, Oktober 2021 halaman 90-101

https://jurnal.amikwidyaloka.ac.id/index.php/awl

jurnal@amikwidyaloka.ac.id/ editor.jurnalwidya@gmail.com

Media : Hardisk

Primary Key : id_klrgsiswa

Foreign Key: id_siswa

Tabel 1.2 Tabel Keluarga Siswa

\begin{tabular}{|c|c|c|c|c|c|}
\hline Field & Type & Length & PK & FK & Keterangan \\
\hline id_klrgsiswa & Int & 11 & $\checkmark$ & & Id keluarga siswa \\
\hline id_siswa & int & 11 & & $\checkmark$ & Dari tabel siswa \\
\hline Nik & Int & 16 & & & $\begin{array}{l}\text { Nomor induk ktp } \\
\text { orang tua siswa }\end{array}$ \\
\hline nama & Varchar & 200 & & & $\begin{array}{l}\text { Nama orang tua } \\
\text { siswa }\end{array}$ \\
\hline tmpt_lahir & Varchar & 100 & & & $\begin{array}{l}\text { Tempat lahir orang } \\
\text { tua siswa }\end{array}$ \\
\hline tgl_lahir & Date & & & & $\begin{array}{l}\text { Tanggal lahir orang } \\
\text { tua siswa }\end{array}$ \\
\hline status_relasi & Varchar & 50 & & & $\begin{array}{l}\text { Status hubungan } \\
\text { dengan siswa } \\
\text { (Ayah/Ibu/Wali) }\end{array}$ \\
\hline agama & Varchar & 50 & & & $\begin{array}{l}\text { Agama orang tua } \\
\text { siswa }\end{array}$ \\
\hline kewarganegaraan & Varchar & 50 & & & $\begin{array}{l}\text { Kewarganegaraan } \\
\text { orang tua siswa }\end{array}$ \\
\hline pendidikan & Varchar & 200 & & & $\begin{array}{l}\text { Pendidikan terakhir } \\
\text { orang tua siswa }\end{array}$ \\
\hline pekerjaan & Varchar & 200 & & & $\begin{array}{l}\text { Pekerjaan orang } \\
\text { tua/wali siswa }\end{array}$ \\
\hline telepon & int & 15 & & & $\begin{array}{lr}\begin{array}{l}\text { Nomor } \\
\text { orang }\end{array} & \text { telepon } \\
\text { siswa } & \text { tua/wali } \\
\end{array}$ \\
\hline
\end{tabular}

c. Tabel Kesehatan Siswa

Nama tabel : siswa

Media : Hardisk

Primary Key: id_kesehatan

Foreign Key: id_Siswa

Tabel 1.3 Tabel Ksesehatan Siswa

\begin{tabular}{|l|l|l|l|l|l|}
\hline Field & Type & Length & PK & FK & Keterangan \\
\hline Id_kesehatan & Int & 11 & $\checkmark$ & & Id kesehatan siswa \\
\hline Id_siswa & Int & 11 & & $\checkmark$ & $\begin{array}{l}\text { Id siswa dari tabel } \\
\text { siswa }\end{array}$ \\
\hline Tahun & Year & & & & $\begin{array}{l}\text { Tahun yang ditempuh } \\
\text { selama siswa di } \\
\text { sekolah }\end{array}$ \\
\hline Berat_bdn & Float & & & & Berat badan siswa \\
\hline Tinggi_bdn & Float & & & & Tinggi badan siswa \\
\hline
\end{tabular}


Volume 2, Nomor 2, Oktober 2021 halaman 90-101

https://jurnal.amikwidyaloka.ac.id/index.php/awl

jurnal@amikwidyaloka.ac.id / editor.jurnalwidya@gmail.com

\begin{tabular}{|l|l|l|l|l|l|}
\hline penyakit & Varchar & 200 & & & $\begin{array}{l}\text { Riwayat Penyakit yang } \\
\text { pernah diderita siswa }\end{array}$ \\
\hline Kelainan-jasmani & Varchar & 200 & & & $\begin{array}{l}\text { Riwayat Kelainan } \\
\text { jasmani yang pernah } \\
\text { diderita siswa }\end{array}$ \\
\hline
\end{tabular}

d. Tabel Mutasi

Nama tabel : siswa

Media : Hardisk

Primary Key : id_mutasi

Foreign Key : id_Siswa

\begin{tabular}{|c|c|c|c|c|c|}
\hline Field & Type & Length & PK & FK & Keterangan \\
\hline Id_mutasi & Int & 11 & $\checkmark$ & & Id mutasi siswa \\
\hline Id_siswa & Int & 11 & & $\checkmark$ & Dari tabel siswa \\
\hline Tahun_tamat & Year & & & & $\begin{array}{l}\text { Tahun tamat belajar } \\
\text { siswa }\end{array}$ \\
\hline Nomor_ijazah & Varchar & 100 & & & $\begin{array}{l}\text { Nomor ijazah siswa } \\
\text { sat lulus }\end{array}$ \\
\hline Melanjutkan_ke & Varchar & 200 & & & $\begin{array}{lr}\text { Setelah } & \text { lulus } \\
\text { tempat } & \text { siswa } \\
\text { melanjutkan } & \text { ke } \\
\text { jenjang selanjutnya }\end{array}$ \\
\hline Dari_tingkat & Varchar & 100 & & & $\begin{array}{l}\text { Tingkat kelas siswa } \\
\text { dari sekolah asal } \\
\text { saat pindah sekolah }\end{array}$ \\
\hline Ke_sekolah & Varchar & 200 & & & $\begin{array}{l}\text { Tujuan sekolah } \\
\text { siswa saat pindah }\end{array}$ \\
\hline Ke_tingkat & Varchar & 200 & & & $\begin{array}{lr}\text { Tingkat } & \text { kelas } \\
\text { saatpindah } & \text { ke } \\
\text { sekolah yang baru }\end{array}$ \\
\hline Tanggal_keluar & Date & & & & Tanggal siswa lulus \\
\hline Tanggal_pindah & Date & & & & $\begin{array}{l}\text { Tanggal siswa saat } \\
\text { pindah sekolah }\end{array}$ \\
\hline Alasan_keluar & Varchar & 200 & & & $\begin{array}{l}\text { Alasan siswa } \\
\text { pindah sekolah. }\end{array}$ \\
\hline
\end{tabular}

\subsection{Flowchart}


Volume 2, Nomor 2, Oktober 2021 halaman 90-101

https://jurnal.amikwidyaloka.ac.id/index.php/awl

jurnal@amikwidyaloka.ac.id / editor.jurnalwidya@gmail.com

Sistem Flowchart di bawah ini menggambarkan rancangan sistem aplikasi pengelolaan baru yang diusulkan setelah penulis analisis sistem sebelumnya. Di sistem flowchart di atas terdapat

Gambar 1 Flowchart Sistem Yang diusulkan

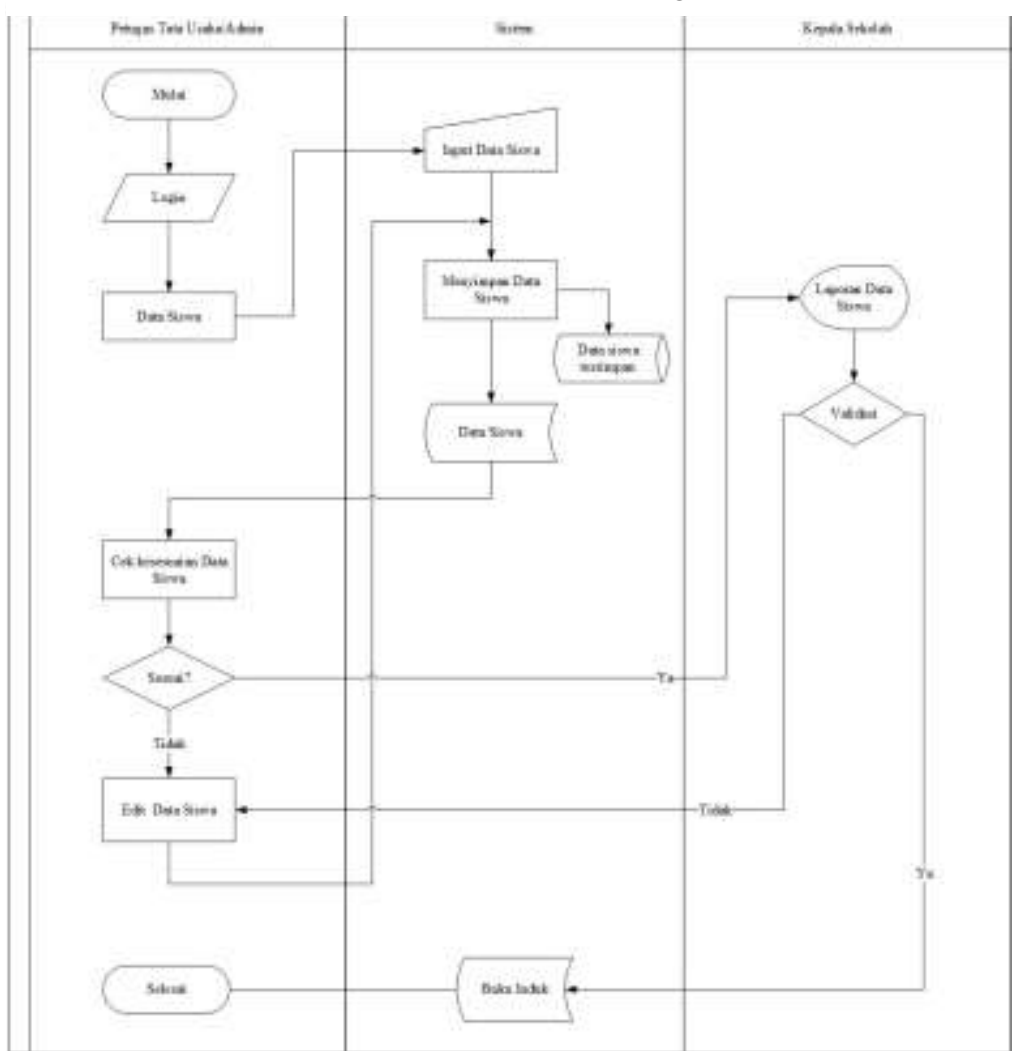

gambaran seluruh rancangan sistem pada aplikasi pengelolaan buku induk siswa berbasis web pada SDN Rawamangun 09.

\subsection{Use Case Diagram}

Perancangan Use Case Diagram pada aplikasi ini dibuat untuk menjelaskan fungsi-fungsi yang terdapat dalam menjalankan aplikasi dan bagaimana fungsi-fungsi tersebut dihubungkan dengan aktor yang terlibat didalamnya. Berikut use case diagram yang diusulkan untuk aplikasi pengelolaan buku induk siswa.

Gambar 2 Use case Digram

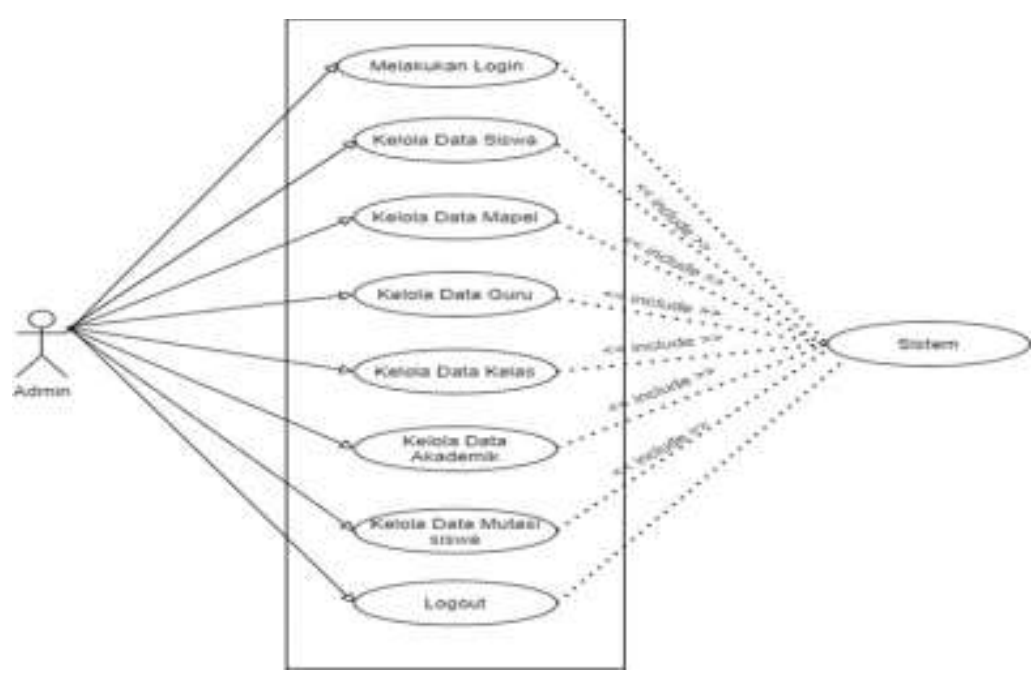


Berdasarkan gambar Use Case diagram yang di usulkan terdapat sebagai berikut :perancangan Aplikasi Buku Induk terdapat srbagai berikut :

1. Sistem mencakup seluruh kegiatan pengelolaan buku induk siswa.

2. Aktor yang melakukan kegiatan adalah admin.

3. 7 use case yang dilakukan oleh aktor, yaitu :
1) Melakukan Login
2) Mengelola data seluruh siswa
3) Mengelola data mata pelajaran
4) Mengelola data guru
5) Mengelola data kelas siswa
6) Mengelola data Akademik siswa
7) Mengelola data mutasi siswa

Gambar 3 Activity Diagram Aplikasi Buku Induk Siswa

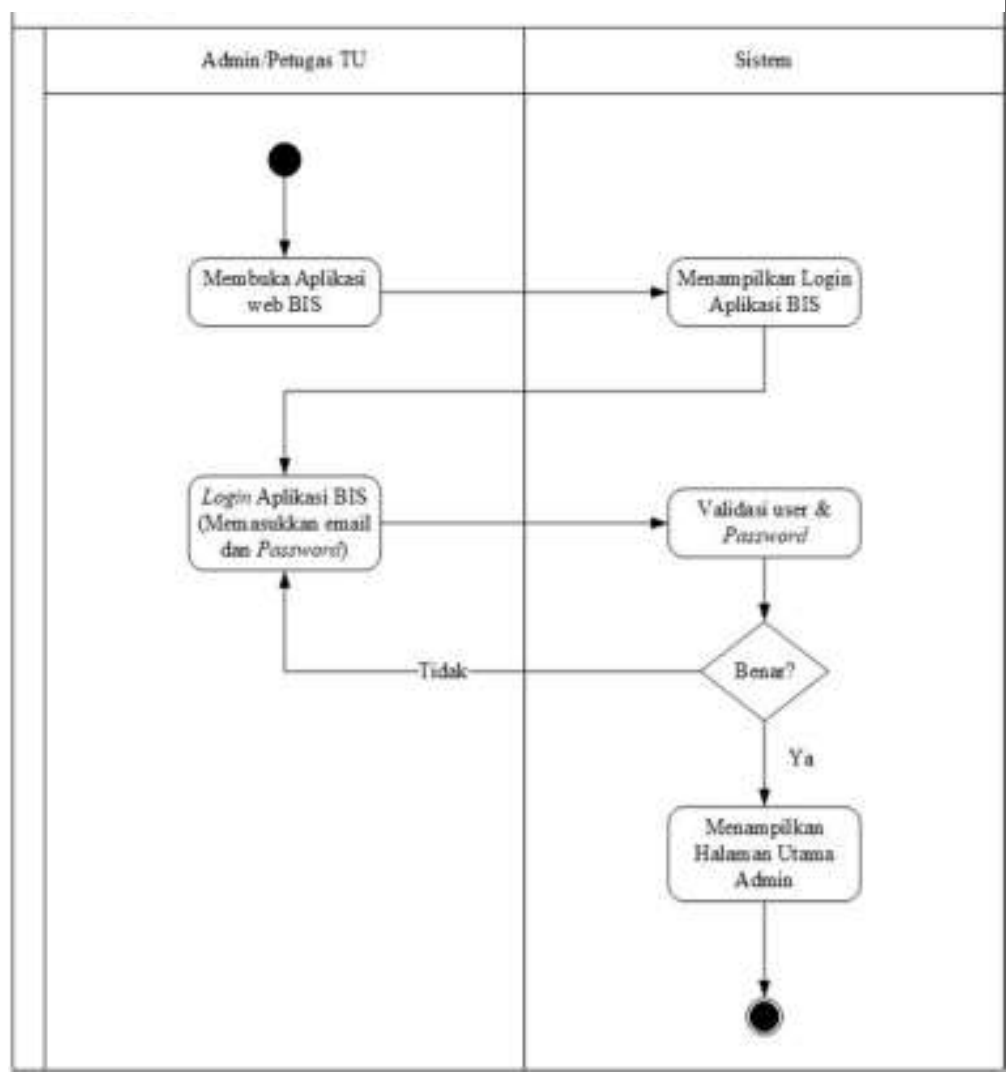

\subsection{Activity Diagram}

Pada activity diagram ini Admin sebagai User. Dimana user melakukan login, setelah itu memasukkan email dan password, apabila berhasil sistem akan merespon dengan menampilkan halaman utama Admin, dan apabila gagal maka sistem akan merespon kembali ke menu email dan password.

\section{Implementasi}

1. Halaman Login 


\section{Jurnal Widya}

Volume 2, Nomor 2, Oktober 2021 halaman 90-101

P-ISSN: 2746-5411

https://jurnal.amikwidyaloka.ac.id/index.php/awl

jurnal@amikwidyaloka.ac.id / editor.jurnalwidya@gmail.com

Gambar 1. Halaman Login

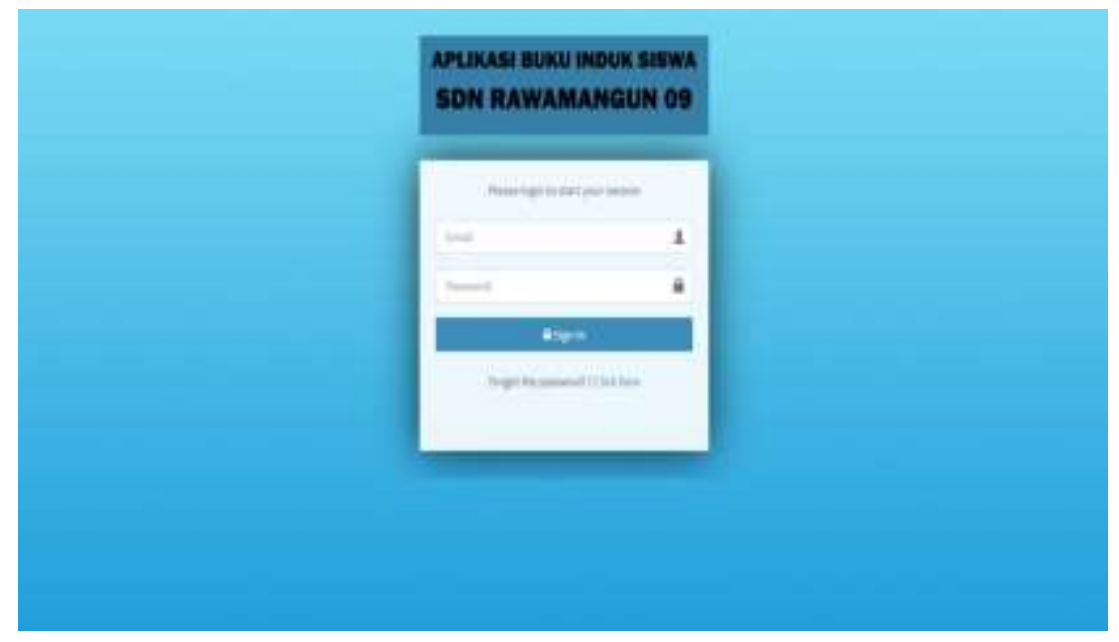

2. Halaman Dasboard

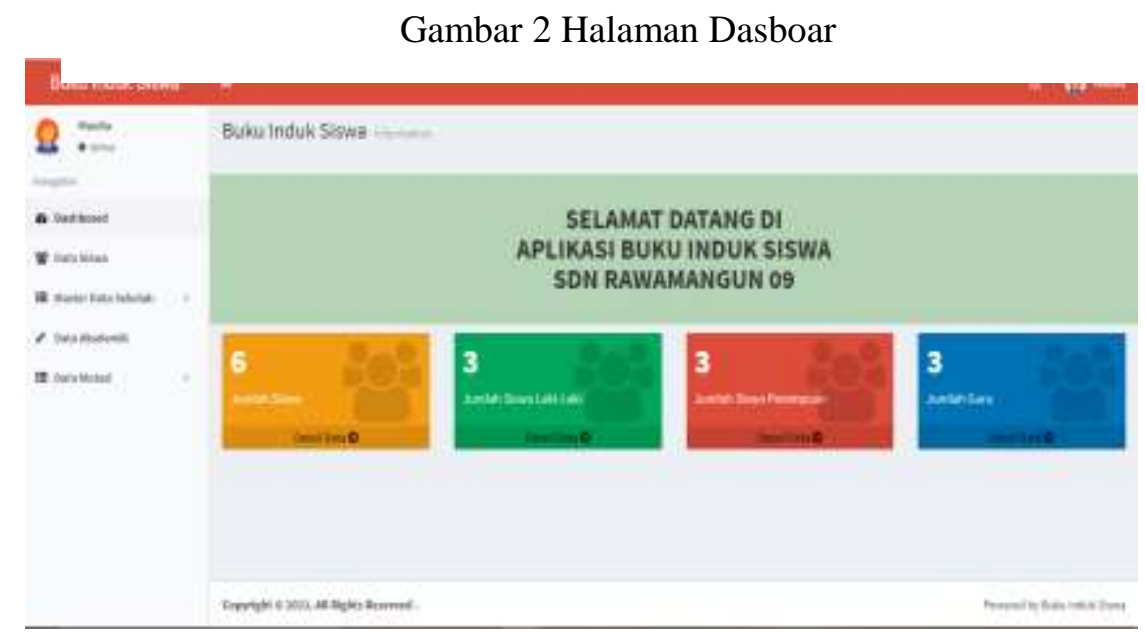

3. Halaman Data Siswa

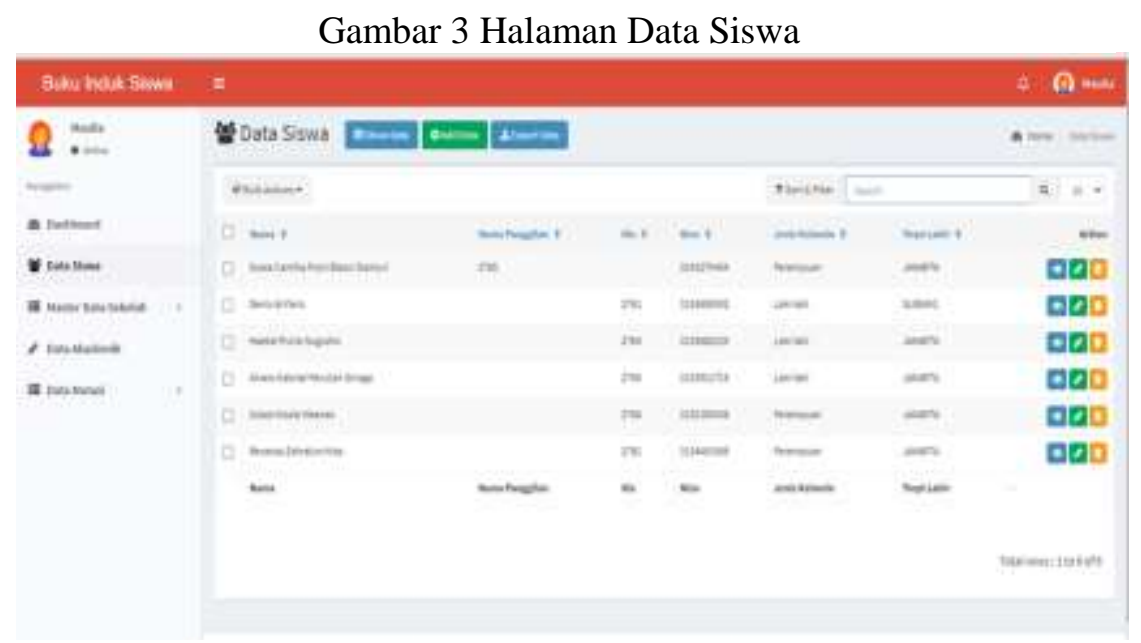


4. Halaman Hasil Laporan Siswa

Gambar 4 Halaman Hasil Laporan Siswa

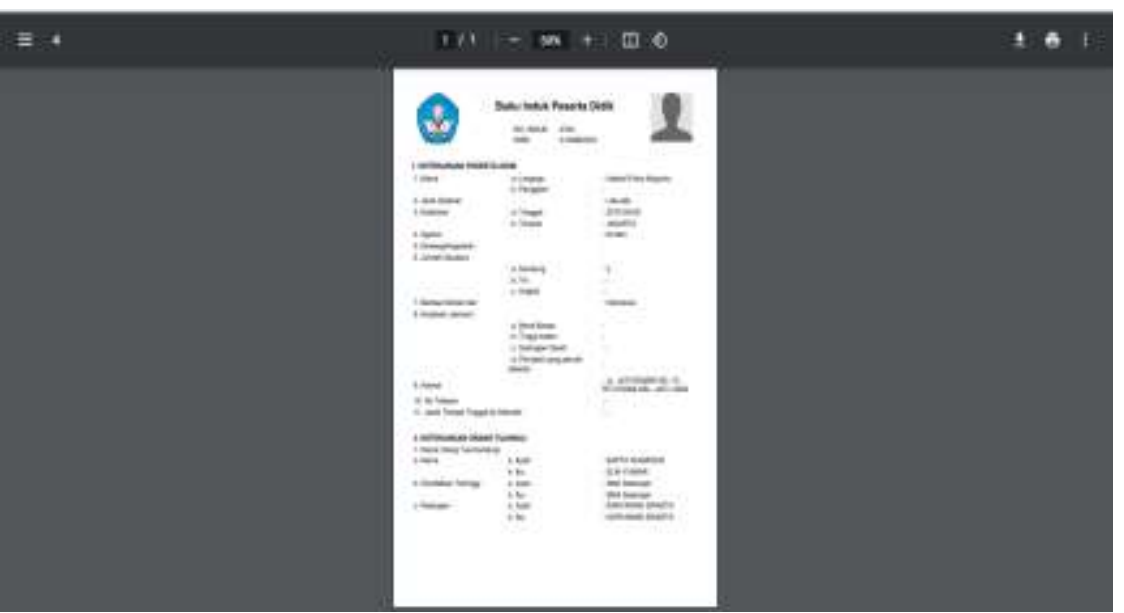

6 Kesimpulan (or Conclusion)

Dengan ini penulis menarik kesimpulan sebagai berikut :

1. Dengan adanya aplikasi web ini data siswa dengan mudah di pantau, baik pengelolaan dan transaksinya sehingga menjadi efektif dan efisien.

2. Mengurangi kesalahan dalam laporan karena sistem akan lebih baik dan ideal dalam pemasukkan Data Siswa .

3. Laporan menjadi lebih berkualitas dan proses lebih efektif karena adanya sistem yang kompleks pada aplikasi berbasis web tersebut

\section{Referensi (Reference)}

[1] L. P. C. Prabandari, "Sistem informasi buku induk siswa," Pendidikan Teknologi dan Kejuruan, pp. 139-148, 2019.

[2] Budiman dan F. Rizkiyah, "RANCANG BANGUN APLIKASI BUKU INDUK SISWA BERBASIS WEB PADA MTs NEGERI KERTAJATI," Prosiding SINTAK 2017, no. 307-311, 2017.

[3] M. M. Chafid, "Perancangan Sistem Informasi Buku Induk Siswa Berbasis Web," Kediri: Jurnal Pendidikan, 2017.

[4] H. Tohari, Analisis Serta Perancangan Sistem Informasi Melalui Pendekatan UML, Yogyakarta: Penerbit Andi, 2014.

[5] Kusrini dan A. Kristanto, Tuntunan Praktis Membangun Sistem Informasi Akuntansi dengan Visual Basic dan SQL Server, Yogyakarta: Penerbit Andi, 2009.

[6] A. Kadir, Pengenalan Sistem Informasi Edisi Revisi, Yogyakarta: Penerbit Andi, 2013.

[7] Adi Mardian, Thomas Budiman, Rachmawaty Haroen; Verdi Yasin (2021), Perancangan Aplikasi Pemantauan Kinerja Karyawan Berbasis Android di PT. Salestrade Corp. Indonesia, "Jurnal Manajemen Informatika Jayakarta”, E-ISSN : 2797-0930 (Online), P-ISSN : 2746-5985 (Print), Volume 1, Nomor 3,Juli 2021, halaman 169-185, DOI: 10.52362/jmijayakarta.v1i3.481, URL Publikasi: http://iournal.stmikjayakarta.ac.id/index.php/JMIJayakarta/article/view/481

[8] Nandang Mulyana, Agus Sulistyanto, Verdi Yasin (2021), Perancangan sistem informasi pengelolaan aset it berbasis web pada pt mandiri axa general insurance, "Jurnal Manajemen 
Informatika Jayakarta", E-ISSN : 2797-0930 (Online), P-ISSN : 2746-5985 (Print), Volume 1, Nomor 3, Juli 2021, halaman 243-257, DOI: 10.52362/jmijayakarta.v1i3.498, URL Publikasi: http://journal.stmikjayakarta.ac.id/index.php/JMIJayakarta/article/view/498

[9] Maulia Usnaini, Verdi Yasin, Anton Zulkarnain Sianipar (2021), Perancangan sistem informasi inventarisasi aset berbasis web menggunakan metode waterfall, "Jurnal Manajemen Informatika Jayakarta", E-ISSN : 2797-0930 (Online), P-ISSN : 2746-5985 (Print) Volume 1, Nomor 1,Februari 2021, halaman 36-55, DOI: 10.52362/imijayakarta.v1i1.415, URL Publikasi: http://journal.stmikjayakarta.ac.id/index.php/JMIJayakarta/article/view/415

[10] Putri Setiani, Ifan Junaedi, Anton Zulkarnain Sianipar, Verdi Yasin (2021), Perancangan sistem informasi pelayanan penduduk berbasis website di rw 010 Kelurahan Keagungan Kecamatan Tamansari - Jakarta Barat, "Jurnal Manajemen Informatika Jayakarta", E-ISSN : 27970930 (Online), P-ISSN : 2746-5985 (Print) Volume 1, Nomor 1,Februari 2021, halaman 20-35, DOI: 10.52362/jmijayakarta.v1i1.414, URL Publikasi: http://journal.stmikjayakarta.ac.id/index.php/JMIJayakarta/article/view/414

[11] Benni Triyono, Sri Purwanti, Verdi Yasin (2017) "Rekayasa Perangkat Lunak Sistem Informasi Pengiriman Dan Penerimaan Surat Atau Paket Berbasis Web", Journal of Information System, Applied, Management, Accounting and Research, e-ISSN: 2598-8719. p-ISSN: 2598-8700.Vol.1 No.1 (30 Desember 2017) p46-53 http://journal.stmikjayakarta.ac.id/index.php/jisamar/article/view/12

[12] Verdi Yasin, Muhammad Zarlis, Mahyuddin K.M. Nasution (2018) "Filsafat Logika Dan Ontologi Ilmu Komputer", Journal of Information System, Applied, Management, Accounting and Research, e-ISSN: 2598-8719. p-ISSN: 2598-8700.Vol.2 No.2 (19 Juni 2018) p68-75 http://journal.stmikjayakarta.ac.id/index.php/iisamar/article/view/39

[13] Julinda Maya Paramudita, Verdi Yasin (2019) "Perancangan Aplikasi Sistem Penyewaan Alat Berat “, Journal of Information System, Applied, Management, Accounting and Research, e-ISSN: 2598-8719. p-ISSN: 2598-8700.Vol.3 No.1 (20 Februari 2019) p23-29 http://iournal.stmikjayakarta.ac.id/index.php/iisamar/article/view/73

[14] Muryan Awaludin, Verdi Yasin (2020) "Application Of Oriented Fast And Rotated Brief (Orb) And Bruteforce Hamming In Library Opencv For Classification Of Plants", Journal of Information System, Applied, Management, Accounting and Research, e-ISSN: 2598-8719. p-ISSN: 2598-8700.Vol.4 No.3 (14 Agustus 2020) p51-59 http://journal.stmikjayakarta.ac.id/index.php/iisamar/article/view/247

[15] Ifan Junaedi, Dimas Abdillah, Verdi Yasin (2020) “Analisis Perancangan Dan Pembangunan Aplikasi Business Intelligence Penerimaan Negara Bukan Pajak Kementerian Keuangan RI", Journal of Information System, Applied, Management, Accounting and Research, e-ISSN: 2598-8719. p-ISSN: 2598-8700.Vol.4 No.3 (14 Agustus 2020) p88-101 http://journal.stmikjayakarta.ac.id/index.php/iisamar/article/view/249

[16] Verdi Yasin (2012) 'Rekayasa Perangkat Lunak Berorientasi Objek”, Penerbit: Mitra Wacana Media, Jakarta-Indonesia.

[17] Anis Rohmadi, Verdi Yasin (2020) "Desain Dan Penerapan Website Tata Kelola Percetakan Pada CV Apicdesign Kreasindo Jakarta Dengan Metode Prototyping", Journal of Information System, Informatics and Computing. E-ISSN: 2597-3673 (Online), P-ISSN: 2579-5201 (Print) Vol. 4 No.1, June 22, 2020. Pp.70-85 http://journal.stmikjayakarta.ac.id/index.php/jisicom/article/view/210

[18] Septian Cahyadi, Verdi Yasin, Mohammad Narji, Anton Zulkarnain Sianipar (2020) "Perancangan Sistem Informasi Pengiriman Dan Penerimaan Soal Ujian Berbasis Web ( Studi Kasus: Fakultas Komputer Universitas Bung Karno)", Journal of Information System, Informatics and Computing. E-ISSN: 25973673 (Online), P-ISSN: 2579-5201 (Print) Vol. 4 No.1, June 22, 2020. Pp.1-16 http://journal.stmikjayakarta.ac.id/index.php/jisicom/article/view/199

[19] Ifan Junaedi, Ndaru Nuswantari, Verdi Yasin (2019) "Perancangan Dan Implementasi Algoritma C4.5 Untuk Data Mining Analisis Tingkat Risiko Kematian Neonatum Pada Bayi”, Journal of Information System, Informatics and Computing. E-ISSN: 2597-3673 (Online), P-ISSN: 2579-5201 (Print) Vol. 3 No.1, February 13, 2019. Pp.29-44. http://journal.stmikjayakarta.ac.id/index.php/jisicom/article/view/203 
[20] Verdi Yasin, Anindra Ramdhan Nugraha, Muhammad Zarlis, Ifan Junaedi (2018) "Smart System Of Fast Internet Access Development Using Backbone Network Method”, Journal of Information System, Informatics and Computing. E-ISSN: 2597-3673 (Online), P-ISSN: 2579-5201 (Print) Vol. 2 No. 2, December 31, 2018. Pp.26-34. http://journal.stmikjayakarta.ac.id/index.php/jisicom/article/view/198

[21] Ito Riris Immasari, Verdi Yasin (2019) "Penggunaan Metode Analytic Hierarchy Process Untuk Menganalisis Faktor-Faktor Yang Mempengaruhi Pemilihan Calon Legislatif Di Dprd Ii Kota Tangerang”, Journal of Information System, Informatics and Computing. E-ISSN: 2597-3673 (Online), P-ISSN: 2579-5201 (Print) Vol. 3 No. 2, December 10, 2019. Pp.53-58. http://journal.stmikjayakarta.ac.id/index.php/jisicom/article/view/139

[22] Verdi Yasin, Muhammad Zarlis, Tulus, Erna Budhiarti Nababan, Poltak Sihombing (2019) "Rancangan Miniatur Otomatisasi Bel Listrik Pada Gerbang Pintu Menggunakan Microkontroler Atmega8535”, Journal of Information System, Informatics and Computing. E-ISSN: 2597-3673 (Online), P-ISSN: 2579-5201 (Print) Vol. 3 No. 1, February 13, 2019. Pp.13-20 http://journal.stmikjayakarta.ac.id/index.php/jisicom/article/view/68

[23] Anggeri S. Nurjaman, Verdi Yasin (2020) "Konsep Desain Aplikasi Sistem Manajemen Kepegawaian Berbasis Web Pada PT. Bintang Komunikasi Utama ”, Journal of Information System, Informatics and Computing. E-ISSN: 2597-3673 (Online), P-ISSN: 2579-5201 (Print) Vol. 4 No. 2, December 28, 2020. Pp.143-174 http://journal.stmikjayakarta.ac.id/index.php/jisicom/article/view/363

[24] Verdi Yasin, Azhar Ahmad Riza, Rumadi Hartawan (2017) "Pengembangan Aplikasi Pemulihan Layanan Bencana Sistem Informasi Peneriman Negara Bukan Pajak Online Di Lingkungan Kementerian Keuangan Republik Indonesia", Journal of Information System, Informatics and Computing. E-ISSN: 2597-3673 (Online), P-ISSN: $2579-5201$ (Print) Vol. 1 No. 1, September 20, 2017. Pp.33-56. http://journal.stmikjayakarta.ac.id/index.php/jisicom/article/view/4 